\title{
Modeling the Rate of Vitamin C Loss in Five Different Fruits During Storage
}

\author{
Timothy Marhiere Akpomie ${ }^{1,}$, Musa Safiyanu Tanko ${ }^{1}$, Umar Faruk Hassan ${ }^{2}$ \\ ${ }^{1}$ Department of Chemistry, Faculty of Science, Federal University of Lafia, Lafia, Nigeria \\ ${ }^{2}$ Department of Chemistry, Faculty of Science, Abubakar Tafawa Balewa University Bauchi, Bauchi, Nigeria \\ Email address: \\ timothy.akpomie@science.fulafia.edu.ng (T. M. Akpomie), safftankomusa@gmail.com (M. S. Tanko), \\ ufhassan2007@gmail.com (U. F Hassan) \\ ${ }^{*}$ Corresponding author
}

\section{To cite this article:}

Timothy Marhiere Akpomie, Musa Safiyanu Tanko, Umar Faruk Hassan. Modeling the Rate of Vitamin C Loss in Five Different Fruits During Storage. Mathematical Modelling and Applications. Vol. 5, No. 4, 2020, pp. 214-220. doi: 10.11648/j.mma.20200504.12

Received: November 8, 2020; Accepted: November 18, 2020; Published: December 25, 2020

\begin{abstract}
Vitamin C, also known as ascorbic acid, in five different fruit samples of orange, mango, watermelon, pawpaw and pineapple were determined with the view of developing suitable mathematical models for subsequent estimation of the vitamin in the fruits after several days of storage at temperatures of 4 and $29\left( \pm 1^{\circ} \mathrm{C}\right)$ respectively prior to consumption. The iodometric titration was used to evaluate the vitamin $\mathrm{C}$ content of the fruit samples alongside their $\mathrm{pH}$ values. Measurements were done on the $1^{\text {st }}, 4^{\text {th }}, 8^{\text {th }}, 12^{\text {th }}$ and $15^{\text {th }}$ day of storage. The results obtained were then fed into a Minitab 18 Statistical Computer programme for model development. The developed model was quadratic in nature and was of the form $\mathrm{y}=\mathrm{c} \pm \mathrm{at} \pm \mathrm{bt} \mathrm{t}^{2}$. For the orange sample, the model at $29^{\circ} \mathrm{C}$ was Vit. $C=15.48-0.2814 t-0.0042 t^{2}$, while at $4^{\circ} \mathrm{C}$, the model was Vit. $C=15.34-$ $0.135 t-0.0099 t^{2}$. Other models were; mango: Vit. $C=8.113-0.3962 t+0.0077 t^{2} \&$ Vit. $C=8.050-0.229 t-0.0011 t^{2}$, watermelon: Vit. $C=5.793-0.573 t+0.0203 t^{2} \&$ Vit. $C=5.338-0.175 t+0.003 t^{2}$, pawpaw: Vit. $C=8.534-0.227 t-0.0069$ $t^{2} \&$ Vit. $C=8.804-0.291 t-0.0009 t^{2}$ and pineapple: Vit. $C=6.459-0.673 t+0.0282 t^{2} \&$ Vit. $C=5.937-0.069 t-0.0044 t^{2}$. All models were found to be highly correlated $\left(\mathrm{r}^{2}=86.90-100.00 \%\right)$ at $95 \%$ confidence level. Simulation using the respective models at 29 and $4{ }^{\circ} \mathrm{C}$ respectively indicated that the initial concentrations of orange (15.45 \pm 1.04$)$, mango (7.82 \pm 1.76$)$, watermelon (6.05 \pm 0.94$)$, pawpaw $(5.48 \pm 0.94)$ and pineapple $\left(8.35 \pm 1.09 \mathrm{mg} / 100 \mathrm{~cm}^{3}\right)$ would respectively take $(36,33),(30$, $31),(23,60),(22,30)$ and $(21,30)$ days to be lost completely. Results also indicated that refrigeration slowed down or conferred some stability on the vitamin $\mathrm{C}$ content except in the orange juice. The percentage losses of vitamin $\mathrm{C}$ in the analytes were found to be: water melon (71.00), pawpaw (60.00), pineapple (58.00), mango (52.00) and orange (35.00) respectively. The respective models could be used to simulate the concentration of vitamin $\mathrm{C}$ at any particular time (days). This would save time and cost of experimentation and would therefore give an estimate of the concentration of the vitamin present in such fruits when refrigerated or stored in the open air given the post-harvest number of days.
\end{abstract}

Keywords: Modeling, Vitamin C, Iodometric Titration and Quadratic

\section{Introduction}

Vitamin $\mathrm{C}$ also known as ascorbic acid is a water soluble anti-oxidant that plays a vital role in protecting the body from infections and diseases. It is not synthesized by the human body and therefore must be acquired from dietary sources primarily from fruits and vegetables [1]. The vitamin is easily absorbed in the body, but cannot be stored and must be consumed on daily basis for optimum health, particularly in guiding against diseases like scurvy (disease of the gums, bones and blood vessels), acts as an antioxidant, a nutrient that chemically binds and neutralizes the tissue-damaging effects of substances in the environment known as free radicals. Vitamin $\mathrm{C}$ is therefore vital for the growth and maintenance of healthy bones, teeth, gums, ligaments and blood vessels. It also plays a role in the formation of collagen, the body's major building protein, a central component of all body organs and plays vital roles in reducing the risk of chronic diseases like cardiovascular diseases and cancer [2]. 
Vitamin C increases the rate of absorption of iron, calcium and folic acid and hence reduces allergic reactions, boosts the immune system, stimulates the formation of bile in the gall bladder and facilitates the excretion of various steroids [3].

Many vitamins are lost in fruits and vegetables during handling, processing and storage. The retaining ability of vitamins under chemical, physical and/or thermal stress is called stability [4]. In the United States for instance, fruits and vegetables grown in the North, may spend up to 5 days in transit following harvest before arriving distribution center. Transportation time for fruits and vegetables grown in the Southern hemisphere for winter and spring consumption ranges from as little as few days if transported by air freight to several weeks if sent by refrigerated ship. At the retail store, fruits and vegetables may further spend 1-3 days on display prior to being purchased by the consumer, who may store them for probably up to 7 or more days prior to consumption. This means that fresh fruits and vegetables may not be consumed for a significant length of time following harvest, during which time nutrient degradation may occur [5].

Most fruits and vegetables are composed of $70-90 \%$ water and once separated from their source of nutrients (tree, plant, or vine); they undergo higher rates of respiration which can lead to moisture loss, quality and nutrient degradation as well as potential microbial spoilage. Changes in the nutrient composition of fruits and vegetables from harvest to consumption depend to a certain degree on the particular nutrient, the commodity and the post-harvest handling, storage and home cooking conditions. Initial nutrient content is affected by the particular cultivar (e.g. red delicious and fuji apples), soil type, production system (conventional, organic etc.) and weather conditions (temperature, humidity, daylight hours etc.) during growth [6]. Fruits and vegetables are generally harvested by hand, with the of roots and tubers, while many commodities meant for exception processing are mechanically harvested. Mechanical harvesting generally causes more stress to the plant tissue and may result in more damage than hand harvesting where nutrient retention is optimized [5].

Vitamin C occurs naturally in many fruits and vegetables, particularly in mango, pineapple, orange, water melon, tomato, citrus fruit, cantaloupe, broccoli, spinach, green pepper, cabbage, pineapple, melons and potatoes. The vitamin is easily destroyed by cooking or canning and on exposure to air and light. A healthy diet generally contains sufficient quantities of ascorbic acid, but the body requires more of the vitamins after serious injury, major surgery, burns and when exposed to extreme temperature. Those that are at risk of deficiency are smokers, women taking contraceptives containing the female sex hormone estrogens and people who live in cities with high concentrations of carbon (II) oxide from traffic. Conflicting evidence shows that taking large doses of ascorbic acid will either prevent the common cold or reduce the severity of its symptoms [6].

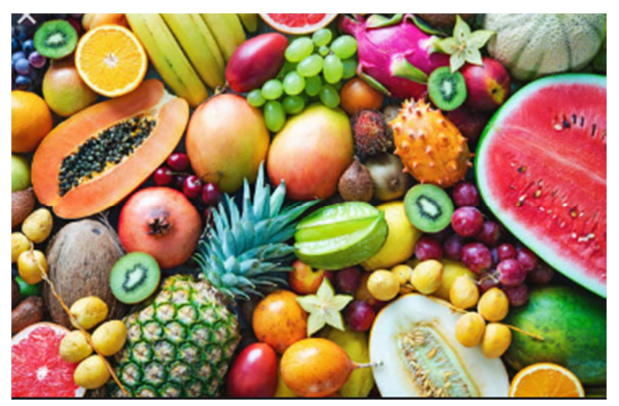

Figure 1. Some Assorted Fruit Samples.

It is a common practice for fruit sellers and consumers to store fruits for a long period of time or even sell them under the sun without prior knowledge of the nutritional deterioration or reduction in the vitamin $\mathrm{C}$ content due to the changing moisture content, temperature and $\mathrm{pH}$. This research work is aimed at developing a model to determine the rate of vitamin $\mathrm{C}$ loss during storage in five different fruits.

\section{Materials and Methods}

In the preparation of all the solutions, chemicals used were of analytical grade and distilled water was also used. All the glass and plastic wares used were thoroughly washed with detergent solution and repeatedly rinsed with water prior to use.

\subsection{Sampling of Fruit Samples}

Five different ripe and fresh samples of fruit namely: Mangifera indica (mango), Ananas comosus (pineapple), Citrus sinesis (orange), Citrllus lanatus (water melon) and Asimina triloba, (pawpaw) were respectively purchased from different farms at Mararaba Akunza, Agyaragun-Tofa and Asakio all in Lafia Local Government Area, Nasarawa State, Nigeria.

\subsection{Treatment of Samples}

Samples were thoroughly washed with water to remove dust and unwanted particles. $100.00 \mathrm{~g}$ of each fruit sample was cut into small pieces and grinded in a blender using $50.00 \mathrm{~cm}^{3}$ of water. The mixture was quantitatively transferred into a $100 \mathrm{~cm}^{3}$ volumetric flask and water was added to capacity [7]. The mixture was then filtered using Whatman Filter Paper Number 1. The resulting analytes were separately kept in screw-capped polyethylene bottles and labeled appropriately for further analysis.

\subsection{Analytical Procedure}

\subsubsection{Determination of Vitamin C}

Aliquot portion $\left(25.00 \mathrm{~cm}^{3}\right)$ of the sample solution prepared in section 2.2 was pipetted into a $250 \mathrm{~cm}^{3}$ conical flask, $150.00 \mathrm{~cm}^{3}$ of water was added. $5.00 \mathrm{~cm}^{3}$ of 0.60 $\mathrm{mol} / \mathrm{dm}^{3}$ of potassium iodide solution was also added to the same conical flask. $5.00 \mathrm{~cm}^{3}$ and $1.00 \mathrm{~cm}^{3}$ of $1.00 \mathrm{~mol} / \mathrm{dm}^{3}$ of hydrochloric acid and starch indicator solution were respectively added. The solution was then titrated with 0.02 $\mathrm{mol} / \mathrm{dm}^{3}$ potassium iodate solution until the end point was 
reached which was the appearance of a permanent trace of dark blue-black color. Each sample was determined in triplicates [7]. The same procedure was used for all the analytes investigated for each of the $1^{\text {st }}, 4^{\text {th }}, 8^{\text {th }}, 12^{\text {th }}$, and $15^{\text {th }}$ day of storage.

\subsubsection{Determination of $\mathrm{pH}$}

The $\mathrm{pH}$ of fruit samples investigated was determined using a $\mathrm{pH}$ meter Model HI 2214/ORP. The instrument was calibrated using $\mathrm{pH} 4.1,7.1$ and 10.1 buffers respectively to check the linearity. $20.00 \mathrm{~cm}^{3}$ of each freshly prepared fruit juice was placed in a glass beaker and the glass electrode was dipped and agitated with a magnetic stirrer for 1 min until reading was stable before being read. Between readings, the electrode was rinsed with distilled water to ensure that no cross-contamination occurred. The $\mathrm{pH}$ of each fruit sample was measured in triplicates. [8,9].

\subsubsection{Modeling Procedure}

The computer statistical software (Minitab 18) was used to automatically generate suitable models for the rate of vitamin $\mathrm{C}$ degradation in all the fruit samples. This was achieved by using the experimental data obtained for each respective fruit The vitamin $\mathrm{C}$ content was used as the response or dependent variable, while the $\mathrm{pH}$ and number of days of storage were used as the independent variables respectively. The statistical validity and strengths of the obtained models (regression equations) were provided alongside the figures using the statistical software.

\section{Results and Discussion}

\subsection{Results}

The variations of vitamin $\mathrm{C}$ contents $\left(\mathrm{mg} / 100 \mathrm{~cm}^{3}\right)$ of all the fruit samples investigated under different days and $\mathrm{pH}$ at $29 \pm 1$ and $4^{\circ} \mathrm{C}$ are depicted in Tables 1 to 5 . The developed model of estimated days for obtaining $0.00 \mathrm{mg} / 100 \mathrm{~cm}^{3}$ of vitamin $\mathrm{C}$ in various fruits at 29 and $4{ }^{\circ} \mathrm{C}$ are presented in Table 6 as well as in Figures 2 to 13. Figure 14 shows the number of days (time) for complete loss of vitamin $\mathrm{C}$ at 29 and $4{ }^{\circ} \mathrm{C}$ in fruit samples, whilst Figure 15 shows the percentage stability of vitamin $\mathrm{C}$ in fruit samples investigated.

Tables 1 to 5 indicated that in all the analytes (fruits), there is an inverse relationship between time (days) and $\mathrm{pH}$ values as well as between time (days) and the concentration of vitamin $\mathrm{C}$. This shows that both $\mathrm{pH}$ and vitamin $\mathrm{C}$ levels continuously decrease with time.
Table 1. Variation of Vitamin C Content $\left(m g / 100 \mathrm{~cm}^{3}\right)$ of Orange Fruit.

\begin{tabular}{lllll}
\hline \multirow{2}{*}{$\begin{array}{l}\text { Time } \\
\text { (Days) }\end{array}$} & At $\mathbf{2 9}^{\mathbf{1}} \mathbf{1}^{\circ} \mathbf{C}$ & \multicolumn{3}{c}{ At $\mathbf{4}^{\circ} \mathbf{C}$} \\
\hline 1 & $\mathbf{p H}$ & [Vitamin $\mathbf{C}]$ & $\mathbf{p H}$ & [Vitamin $\mathbf{C ]}$ \\
\hline 4 & $3.6 \pm 0.05$ & $15.45 \pm 1.04$ & $3.6 \pm 0.05$ & $15.45 \pm 1.04$ \\
8 & $3.1 \pm 0.09$ & $13.85 \pm 0.66$ & $3.5 \pm 0.22$ & $14.25 \pm 2.21$ \\
12 & $2.7 \pm 0.08$ & $12.95 \pm 0.76$ & $3.3 \pm 0.28$ & $13.45 \pm 0.25$ \\
15 & $2.5 \pm 0.04$ & $10.05 \pm 0.54$ & $2.7 \pm 0.93$ & $10.75 \pm 2.14$ \\
\hline
\end{tabular}

Values are mean \pm standard deviation $(n=3)$.

Table 2. Variation of Vitamin C Content $\left(\mathrm{mg} / 100 \mathrm{~cm}^{3}\right)$ of Mango Fruit.

\begin{tabular}{lllll}
\hline \multirow{2}{*}{$\begin{array}{l}\text { Time } \\
\text { (Days) }\end{array}$} & At $\mathbf{2 9} \pm \mathbf{1}^{\circ} \mathbf{C}$ & \multicolumn{3}{c}{ At $\mathbf{4}^{\circ} \mathbf{C}$} \\
\cline { 2 - 5 } & $\mathbf{p H}$ & [Vitamin $\mathbf{C}$ ] & pH & [Vitamin $\mathbf{C}$ ] \\
\hline 1 & $5.8 \pm 0.14$ & $7.82 \pm 1.76$ & $5.8 \pm 0.14$ & $7.82 \pm 1.76$ \\
4 & $5.4 \pm 0.31$ & $6.32 \pm 1.32$ & $5.6 \pm 0.28$ & $7.12 \pm 0.84$ \\
8 & $5.2 \pm 0.41$ & $5.32 \pm 0.86$ & $5.4 \pm 0.06$ & $6.12 \pm 1.05$ \\
12 & $5.0 \pm 0.27$ & $4.77 \pm 0.43$ & $5.2 \pm 0.06$ & $5.17 \pm 1.30$ \\
15 & $4.9 \pm 0.50$ & $3.75 \pm 0.56$ & $5.1 \pm 0.12$ & $4.35 \pm 0.88$ \\
\hline
\end{tabular}

Values are mean \pm standard deviation $(n=3)$

Table 3. Variation of Vitamin C Content $\left(\mathrm{mg} / 100 \mathrm{~cm}^{3}\right)$ of Water Melon Fruit.

\begin{tabular}{lllll}
\hline Time & At $\mathbf{2 9}^{\mathbf{1}} \mathbf{1}^{\circ} \mathbf{C}$ & \multicolumn{3}{c}{ At $\mathbf{4}^{\circ} \mathbf{C}$} \\
\cline { 2 - 5 } (Days) & $\mathbf{p H}$ & [Vitamin $\mathbf{C}$ ] & $\mathbf{p H}$ & [Vitamin $\mathbf{C}$ ] \\
\hline 1 & $4.5 \pm 0.60$ & $6.05 \pm 0.94$ & $4.5 \pm 0.60$ & $6.05 \pm 0.94$ \\
4 & $4.3 \pm 0.06$ & $3.75 \pm 0.96$ & $4.4 \pm 0.82$ & $5.25 \pm 1.27$ \\
8 & $4.1 \pm 0.29$ & $3.05 \pm 1.05$ & $4.3 \pm 0.80$ & $5.15 \pm 1.05$ \\
12 & $3.9 \pm 0.91$ & $2.65 \pm 0.91$ & $4.1 \pm 0.73$ & $4.74 \pm 0.37$ \\
15 & $3.8 \pm 0.78$ & $2.55 \pm 0.90$ & $3.9 \pm 0.49$ & $3.72 \pm 0.71$ \\
\hline
\end{tabular}

Values are mean \pm standard deviation $(n=3)$.

Table 4. Variation of Vitamin C Content $\left(\mathrm{mg} / 100 \mathrm{~cm}^{3}\right)$ of Pawpaw Fruit.

\begin{tabular}{lllll}
\hline \multirow{2}{*}{$\begin{array}{l}\text { Time } \\
\text { (Days) }\end{array}$} & At $\mathbf{2 9} \pm \mathbf{1}^{\circ} \mathbf{C}$ & \multicolumn{3}{c}{ At $\mathbf{4}^{\circ} \mathbf{C}$} \\
\cline { 2 - 5 } & $\mathbf{p H}$ & [Vitamin $\mathbf{C ]}$ & $\mathbf{p H}$ & [Vitamin $\mathbf{C}]$ \\
\hline 1 & $5.4 \pm 0.16$ & $5.48 \pm 0.94$ & $5.4 \pm 0.16$ & $5.48 \pm 0.94$ \\
4 & $5.0 \pm 0.31$ & $3.36 \pm 0.91$ & $5.2 \pm 0.70$ & $4.05 \pm 0.64$ \\
8 & $4.7 \pm 0.37$ & $2.65 \pm 0.61$ & $4.9 \pm 0.04$ & $3.65 \pm 0.25$ \\
12 & $4.4 \pm 0.08$ & $2.10 \pm 0.30$ & $4.6 \pm 0.04$ & $3.40 \pm 0.03$ \\
15 & $4.1 \pm 0.11$ & $1.60 \pm 0.51$ & $4.2 \pm 0.08$ & $1.60 \pm 0.21$ \\
\hline
\end{tabular}

Values are mean \pm standard deviation $(n=3)$.

Table 5. Variation of Vitamin C Content $\left(\mathrm{mg} / 100 \mathrm{~cm}^{3}\right)$ of Pineapple Fruit.

\begin{tabular}{lllll}
\hline \multirow{2}{*}{$\begin{array}{l}\text { Time } \\
\text { (Days) }\end{array}$} & At $\mathbf{2 9} \pm \mathbf{1}^{\circ} \mathbf{C}$ & \multicolumn{3}{c}{ At $\mathbf{4}^{\circ} \mathbf{C}$} \\
\cline { 2 - 5 } & $\mathbf{p H}$ & [Vitamin $\mathbf{C}$ ] & $\mathbf{p H}$ & [Vitamin $\mathbf{C}$ ] \\
\hline 1 & $5.6 \pm 0.05$ & $8.35 \pm 1.09$ & $5.6 \pm 0.05$ & $8.35 \pm 1.09$ \\
4 & $5.2 \pm 0.32$ & $7.55 \pm 1.43$ & $5.3 \pm 0.06$ & $7.95 \pm 0.77$ \\
8 & $4.9 \pm 0.09$ & $5.90 \pm 0.76$ & $5.1 \pm 0.10$ & $6.30 \pm 0.55$ \\
12 & $4.7 \pm 0.07$ & $5.35 \pm 0.74$ & $4.9 \pm 0.05$ & $5.05 \pm 0.29$ \\
15 & $4.2 \pm 0.14$ & $3.35 \pm 0.77$ & $4.5 \pm 0.13$ & $4.35 \pm 1.03$ \\
\hline
\end{tabular}

Values are mean \pm standard deviation $(n=3)$.

Table 6. Developed Models used to Estimate $0.00 \mathrm{mg} / 100 \mathrm{~cm}^{3}$ of Vitamin C in Analyzed Fruit Samples.

\begin{tabular}{llll}
\hline Fruits & Model At $\mathbf{2 9} \pm \mathbf{1}^{\circ} \mathbf{C}$ & Model At $\mathbf{4}^{\circ} \mathbf{C}$ & Days \\
\hline Orange & Vit. $C=15.48-0.2814 t-0.0042 t^{2}$ & Vit. $C=15.34-0.135 t-0.0099 t^{2}$ \\
Mango & Vit. $C=8.113-0.3962 t+0.0077 t^{2}$ & Vit. $C=8.050-0.229 t-0.0011 t^{2}$ \\
Water Melon & Vit. $C=5.793-0.573 t+0.0203 t^{2}$ & days & $30 \& 31$ \\
Pawpaw & Vit. $C=8.534-0.227 t-0.0069 t^{2}$ & Vit. $C=8.338-0.175 t+0.003 t^{2}$ \\
Pineapple & Vit. $C=6.459-0.673 t+0.0281 t-0.0009 t^{2}$ & $22 \& t^{2}$ & 28 \\
\hline
\end{tabular}




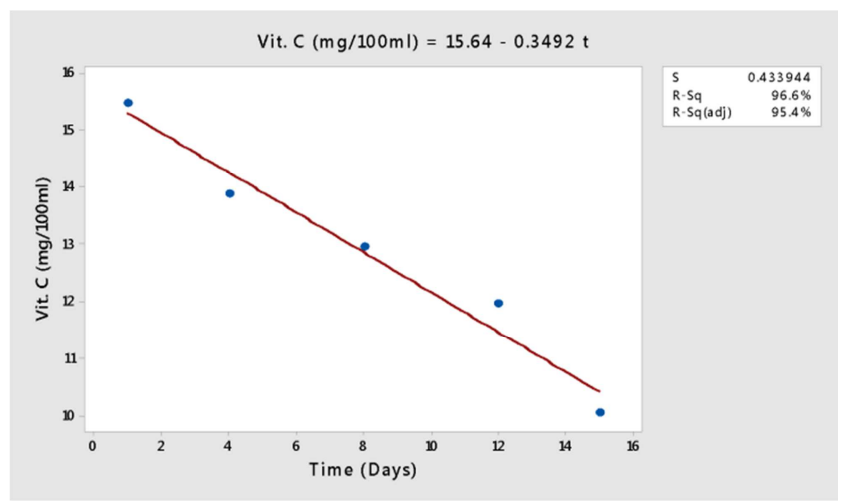

Figure 2. Linear Model of Orange at $29 \pm 1^{\circ} \mathrm{C}$.

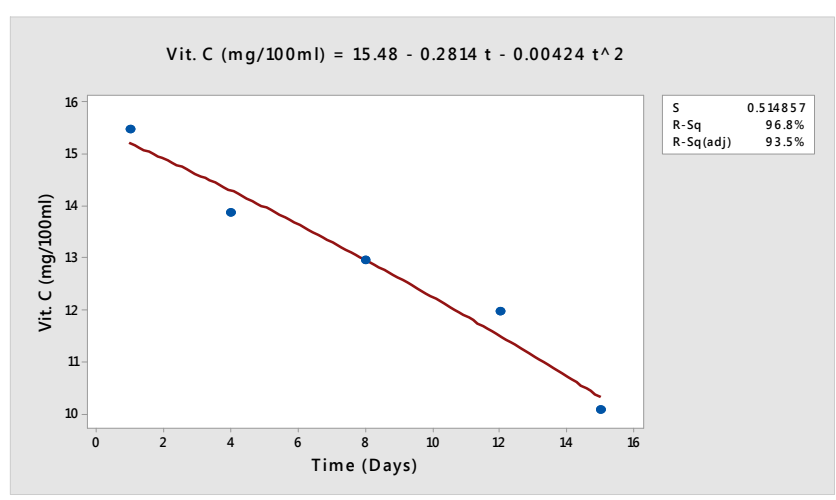

Figure 3. Quadratic Model of Orange at $29 \pm 1^{\circ} \mathrm{C}$.

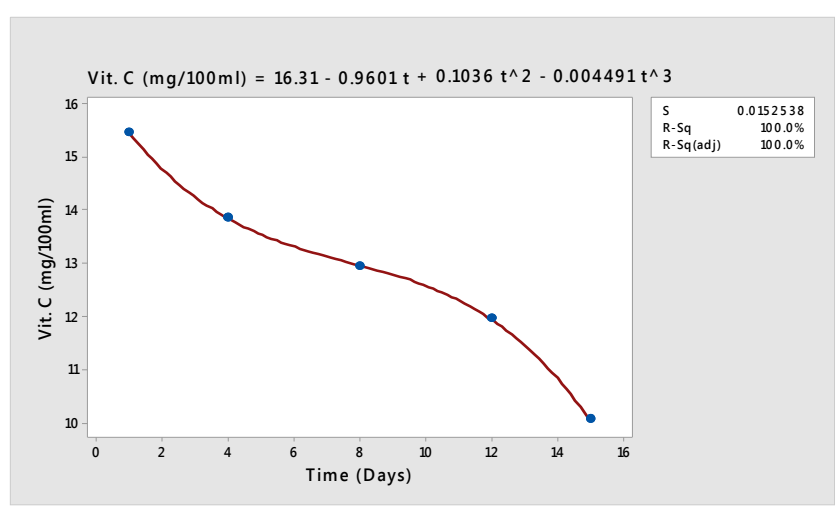

Figure 4. Cubic Model of Orange at $29 \pm 1{ }^{\circ} \mathrm{C}$.

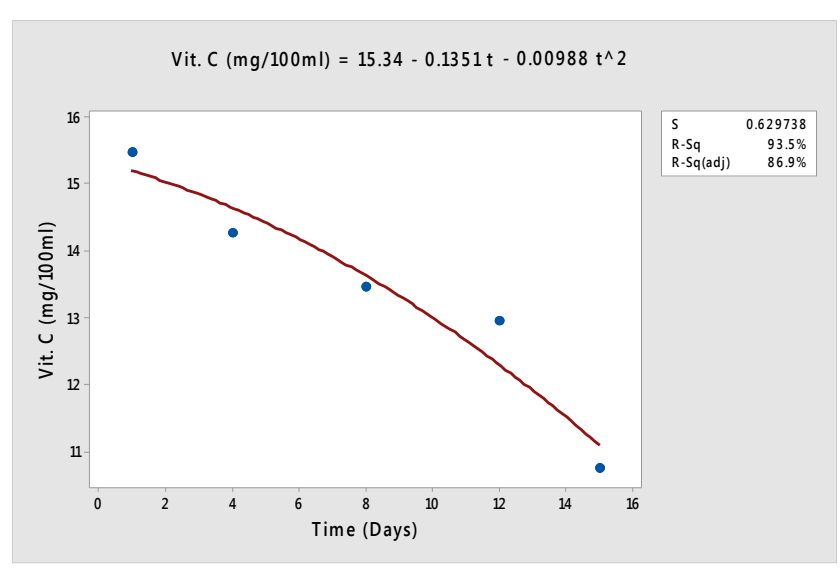

Figure 5. Quadratic Model of Orange at $4^{\circ} \mathrm{C}$.

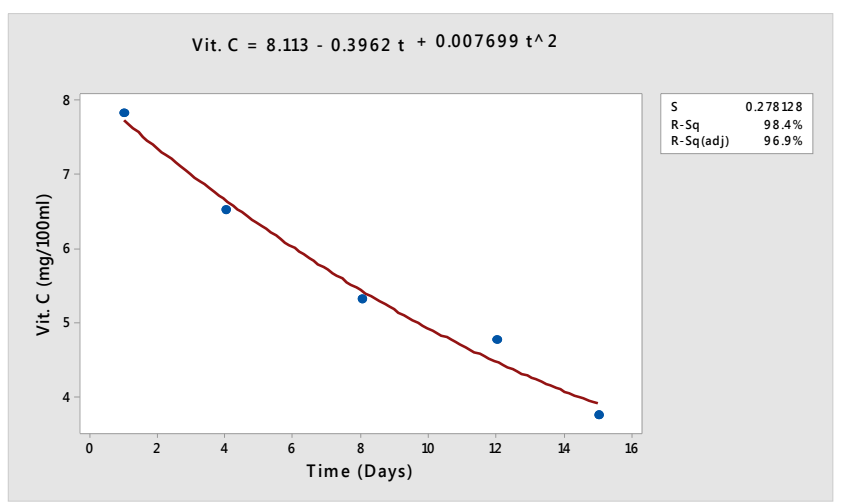

Figure 6. Quadratic Model of Mango Fruit at $29 \pm 1{ }^{\circ} \mathrm{C}$.

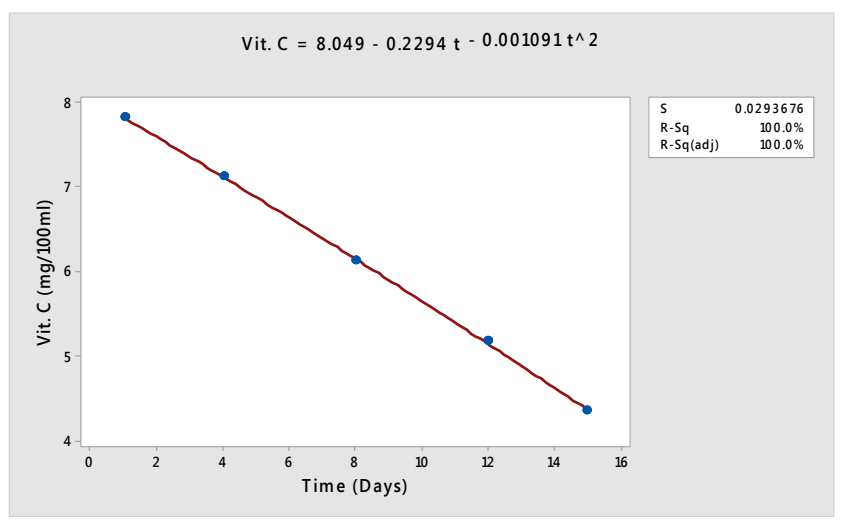

Figure 7. Quadratic Model of Mango Fruit at $4^{\circ} \mathrm{C}$.

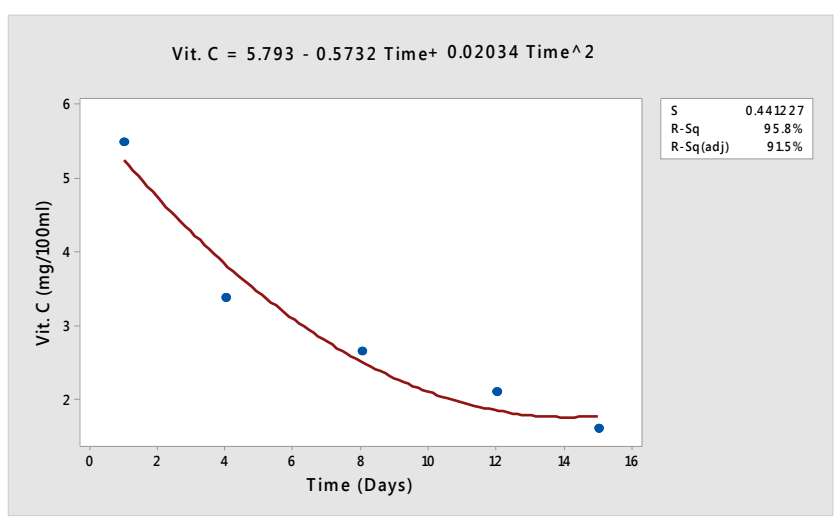

Figure 8. Quadratic Model of Water Melon at $29 \pm 1{ }^{\circ} \mathrm{C}$.

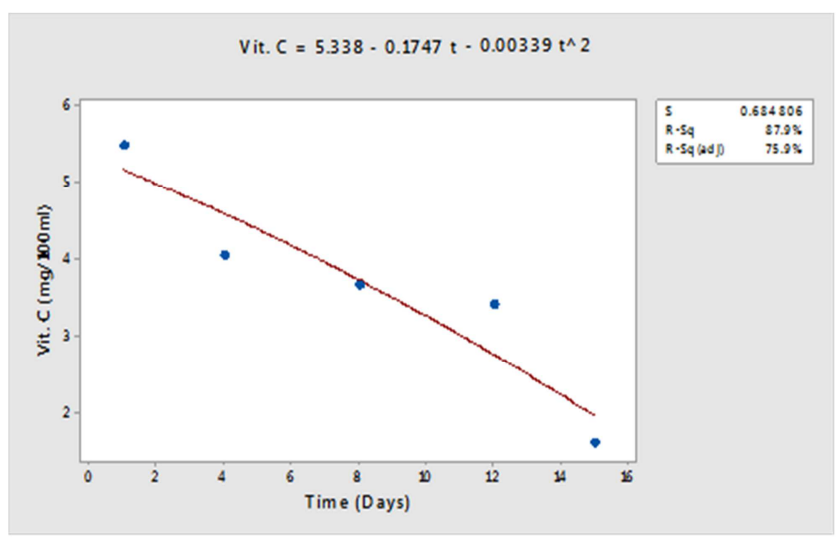

Figure 9. Quadratic Model of Water Melon Fruit at $4^{\circ} \mathrm{C}$. 


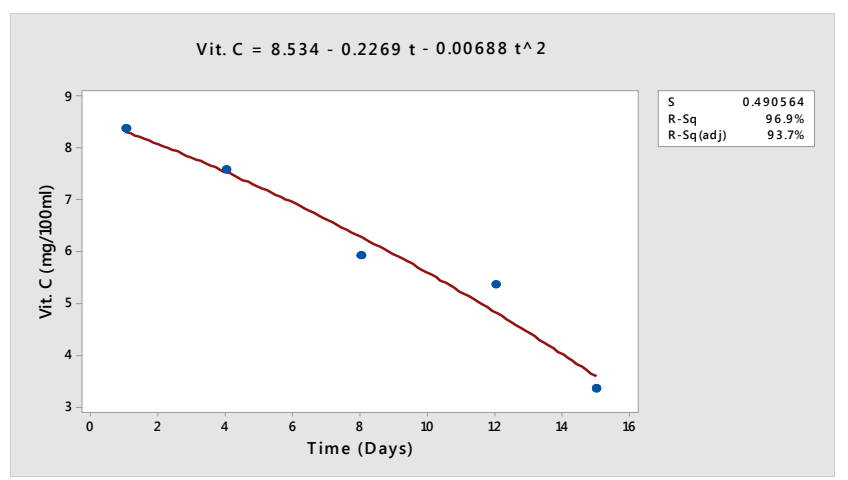

Figure 10. Quadratic Model of Pawpaw at $29 \pm 1^{\circ} \mathrm{C}$.

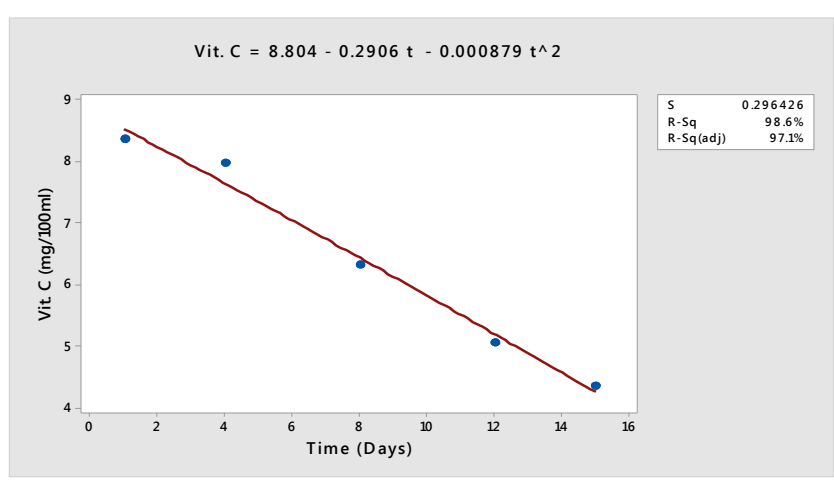

Figure 11. Quadratic Model of Pawpaw at $4^{\circ} \mathrm{C}$.

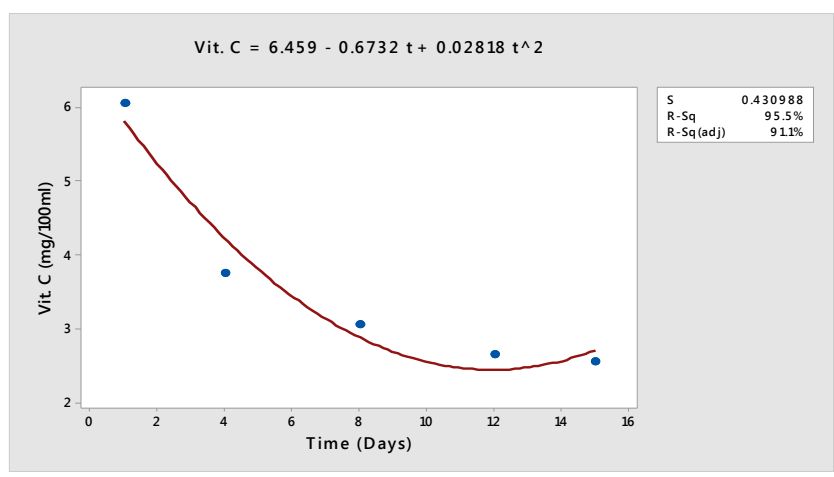

Figure 12. Quadratic Model of Pineapple at $29 \pm 1^{\circ} \mathrm{C}$.

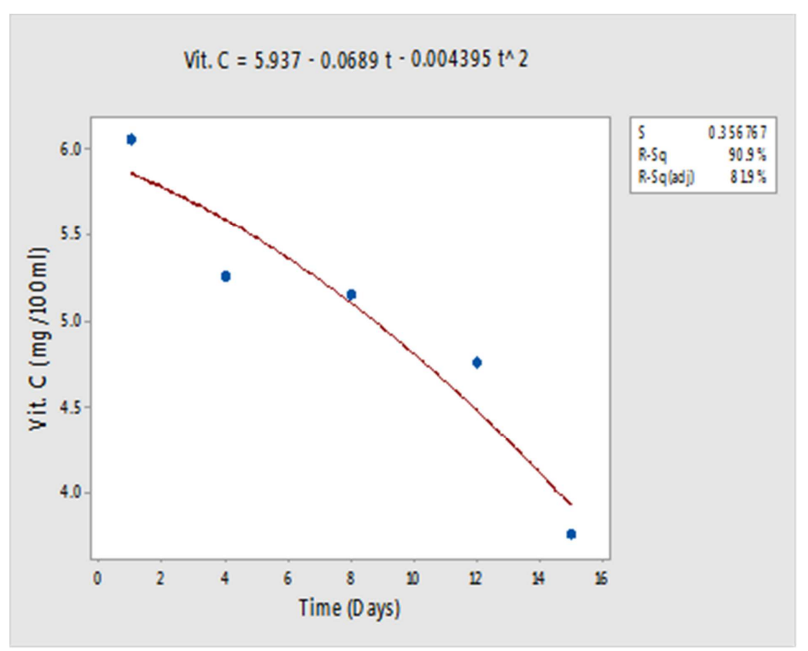

Figure 13. Quadratic Model of Pineapple at $4^{\circ} \mathrm{C}$.

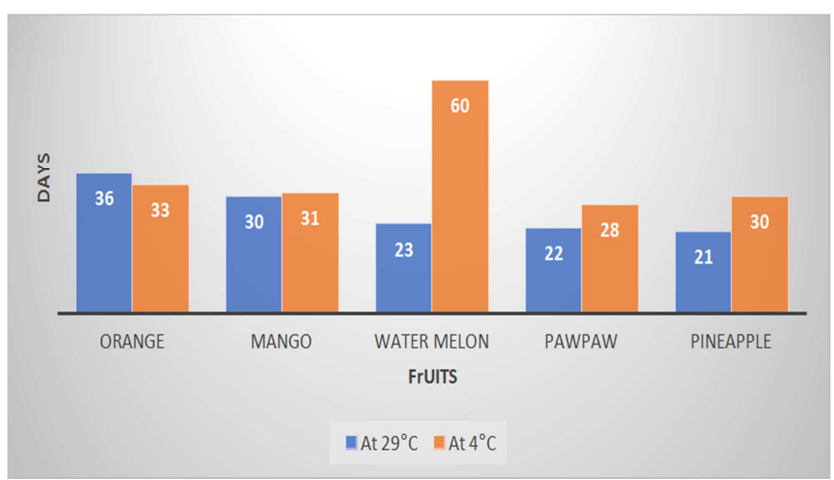

Figure 14. Number of Days (Time) for Complete Loss of Vitamin C in Fruit Samples at 29 and $4{ }^{\circ} \mathrm{C}$.

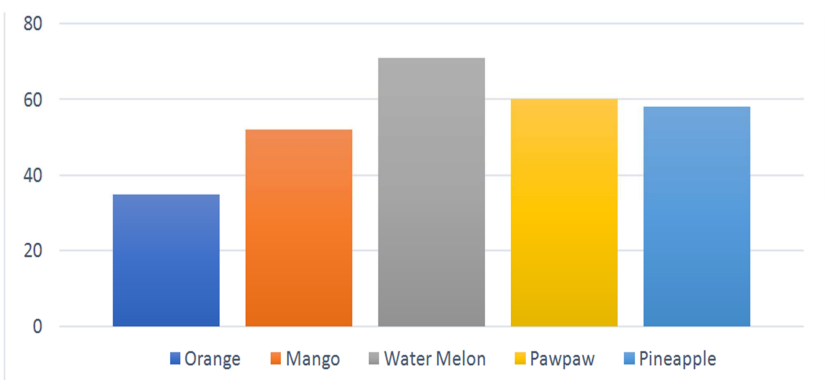

Figure 15. Percentage Stability of Vitamin C in Fruit Samples.

\subsection{Discussion}

Figures 2, 3 and 4 showed the linear, quadratic and cubic models respectively developed from the observed mean concentrations of vitamin $\mathrm{C}$ in the orange fruit samples investigated at room temperatures of between $28-30^{\circ} \mathrm{C}$. In all the three models, the predictor was found to be the time variable as it correlated highly $\left(\mathrm{r}^{2}=0.954,0.934\right.$ and 1 respectively) with the vitamin $\mathrm{C}$ content as given by the Minitab statistical software. The $\mathrm{pH}$ showed little or no correlation with the vitamin $\mathrm{C}$ content of the fruit, hence the $\mathrm{pH}$ was said to be inestimable. The changes in $\mathrm{pH}$ may be as a result of the biochemical reactions and microbial actions that occurred during the storage period in the orange juice and this may not necessarily be responsible for the degradation or reduction in vitamin $\mathrm{C}$ level. By using any of the models and given any number of days, the quantity of vitamin $\mathrm{C}$ present in the fruit may be estimated at $95 \%$ confidence level.

As regards the three models, the quadratic model was found to be the most suitable. This is because the linear model whose regression line assumed a perfect linear relationship between the dependent and independent variables (quantity of vitamin $\mathrm{C}$ and number of days or time) and the cubic model whose regression line was the same as the actual observations and that was why its coefficient of correlation was observed to be $100 \%$. This in reality, may not be so. The quadratic model, not linear in nature and whose line of best fit was not the same as the actual observations was therefore more appropriate for estimating the quantity of vitamin $\mathrm{C}$ in the orange sample.

Figure 5 shows the quadratic model for estimating the 
quantity of vitamin $\mathrm{C}$ in the orange fruit at a refrigerated temperature of $4^{\circ} \mathrm{C}$. This model showed a similar trend with that of orange at $29 \pm 1^{\circ} \mathrm{C}$ and its coefficient of correlation $\left(\mathrm{r}^{2}\right)$ was observed to be $86.9 \%$.

Figures 6 and 7 are the derived models for the quantitative estimation of vitamin $\mathrm{C}$ content of the mango fruits investigated at the respective temperatures. Both models also followed a similar trend with that of the orange sample. The coefficients of correlation $\left(\mathrm{r}^{2}=98.40\right.$ and $\left.100.00 \%\right)$ for the degradation of the mango fruit at the respective temperatures was higher than those of orange. The model for the degradation at $4^{\circ} \mathrm{C}$ in the mango fruit showed a $100.00 \%$ inverse relationship between concentrations of vitamin $\mathrm{C}$ and the number of days of storage.

A trend similar to orange and mango fruits is portrayed in the models of water melon as illustrated in Figures 8 and 9, $\mathrm{r}^{2}$ was 95.8 and $87.9 \%$ at 29 and $4^{\circ} \mathrm{C}$ in that order.

The models for Pawpaw are depicted in Figures 10 and 11 respectively at 29 and $4{ }^{\circ} \mathrm{C}$. The coefficients of correlation $\left(\mathrm{r}^{2}\right)$ in both models were observed to be 96.90 and $98.60 \%$ respectively. It is evident that there is a high degree of association between Vitamin $\mathrm{C}$ and time variables.

The developed model used in forecasting the concentration of vitamin $\mathrm{C}$ in pineapple fruit based on the number of days of storage and at 29 and $4{ }^{\circ} \mathrm{C}$ are presented in Figures 12 and 13. The variables of the models were also noted to be highly correlated $\left(\mathrm{r}^{2}=95.50\right.$ and $\left.90.90 \%\right)$.

Table 6 shows that the models follow the quadratic form, $y=c \pm a t \pm b t^{2}$, where $\mathrm{y}$ is the quantity of vitamin $\mathrm{C}$ in the fruit, ' $a$ ' and ' $b$ ' are the coefficients of determination or slope as evaluated by the statistical package while ' $c$ ' represents the constant term or intercept respectively, and ' $t$ ' is the number of days of observation or storage.

The models at 29 and $4{ }^{\circ} \mathrm{C}$ of the fruit samples revealed that it would take approximately 36 and 33 days respectively for complete loss or reduction of vitamin $\mathrm{C}$ in orange, mango at $29^{\circ} \mathrm{C}$ would require 30 days for complete reduction, while at $4{ }^{\circ} \mathrm{C}$; the same fruit (mango) will take 31 days to reduce to $0.00 \mathrm{mg} / 100 \mathrm{~cm}^{3}$. Similarly, watermelon, pawpaw and pineapple at 29 and $4{ }^{\circ} \mathrm{C}$ would require 23 and 60,22 and 28 as well as 21 and 30 days to be degraded completely. This is illustrated in Figure 14.

The general trend as seen in Figure 14 showed clearly that refrigeration of the various fruit samples conferred some form of stability or preservation on the ascorbic acid content. The vitamin $\mathrm{C}$ content took longer time (days) to be reduced to $0.00 \mathrm{mg} / 100 \mathrm{~cm}^{3}$ or lost completely at $4{ }^{\circ} \mathrm{C}$, but took a shorter time for similar observations at $29^{\circ} \mathrm{C}$. This is because vitamin $\mathrm{C}, \mathrm{C}_{6} \mathrm{H}_{8} \mathrm{O}_{6}$, is known to be very vulnerable towards heat and the proximity of the highly electronegative oxygen atoms on the hydroxyl $(\mathrm{OH})$ groups makes the hydrogen atoms to become easily detached from the structure. In the presence of heat, this causes the hydroxyl bond to break and the ascorbic acid is said to undergo "destruction" or oxidation by losing hydrogen atoms, forming dehydroascorbic acid. This implies that the rate of ascorbic acid destruction is significantly greater at higher temperature hence the reduced vitamin c content [10].

This trend was also observed and reported by [11-14] in several other studies on ascorbic acid determination in fruits. An exception to this trend was however noted in the orange fruit juice, where it was observed that reduction of the vitamin c content to $0.00 \mathrm{mg} / 100 \mathrm{~cm}^{3}$ was faster at $4^{\circ} \mathrm{C}$ than at $29^{\circ} \mathrm{C}$. This observation may not be out of place since [15] had reported that the loss of vitamin $\mathrm{C}$ with time differs from one fruit to the other under similar storage environments. Additionally, a further study by [12] on the loss of vitamin c in orange, lemon, lime, pineapple, paw-paw and carrot fruit juices, found that only in orange was the organisms Bacillus subtilis and Candida sp. was not isolated. The presence of these species in the other fruit samples at room temperature may be the catalyst for the instability of the vitamin at that temperature and the converse for the orange fruit.

The loss of vitamin $\mathrm{C}$ observed in water melon, pawpaw, pineapple, mango and orange were found to be 71.00, 60.00, $58.00,52.00$ and $35.00 \%$ respectively. The models of the fruit samples could be used to simulate the concentration of vitamin $\mathrm{C}$ at any particular time (days) by substituting the number of days in the appropriate model and would therefore save time and cost of experimentation.

\section{Conclusion}

Several models were developed for evaluating the rate of loss of vitamin $\mathrm{C}$ in five different fruit samples. The developed models were quadratic in nature and of the form, $y=c \pm$ $a t \pm b t^{2}$. The parameters of the model for all the fruit samples at $29 \pm 1{ }^{\circ} \mathrm{C}$ and $4 \pm 1{ }^{\circ} \mathrm{C}$ were highly correlated $\left(r^{2}=86.90-\right.$ $100.00 \%$ ) at $95 \%$ confidence level. Application of the respective models for all fruit samples revealed that: orange was simulated to take 36 and 33 days for its vitamin $\mathrm{C}$ content to be completely lost at 29 and $4\left( \pm 1^{\circ} \mathrm{C}\right)$ respectively, mango wound require 30 and 31 days, water melon would take 23 and 60 days, pawpaw would need 22 and 28 days and pineapple would require 21 and 30 days. Loss of vitamin $\mathrm{C}$ was generally observed to be slower at a refrigerated temperature of $4 \pm 1^{\circ} \mathrm{C}$ in all the fruit samples except in orange which was more stable or slower at $29 \pm 1{ }^{\circ} \mathrm{C}$. The order of stability of vitamin $\mathrm{C}$ in decreasing magnitude for all the fruit samples was: water melon $>$ pawpaw $>$ pineapple $>$ mango $>$ orange.

\section{References}

[1] Lee, S. K. \& Kader, A. A. (2000). Pre-harvest and Postharvest Factors Influencing Vitamin C Content of Horticultural Crops. Post-harvest Biology and Technology, 20 (3): 207-220.

[2] Leong, S. L \& Oey, I. (2012). Effect of Endogenous Ascorbic Acid Oxidase Activity and Stability on Vitamin C in Carrots (Daucus carota subsp. sativus) during Thermal Treatment. Food Chemistry, 134 (4): 2075-2085.

[3] Abbasi, A. \& Niakousari, M. (2008). Kinetics of Ascorbic Acid Degradation in Un-pasteurized Iranian Lemon Juice during Regular Storage Conditions, Pak. J. Biol. Sci., 11: $1365-1369$. 
[4] Burdurlu, H. S., Koca, N. \& Keradeniz, F. (2006): Degradation of vitamin $\mathrm{C}$ in citrus juice concentrate during storage. Journal of Food Engineering, 7 (2): 211-216.

[5] Rickman, J. C., Barrett, D. M. \& Bruhn, C. M. (2007). Nutritional Comparison of Fresh, Frozen and Canned Fruits and Vegetables. Vitamins $\mathrm{C}$ and $\mathrm{B}$ and Phenolic Compounds. $J$. Sci. Food Agric. Vol 87 (5) pp 930-944.

[6] Howard, L., Wong, A., Perry, A. \& Klein, B. (1999). ßCarotene and Ascorbic Acid Retention in Fresh and Processed Vegetables. J. Food Sci., 64: 929-936.

[7] Harris, J. R., (2003). Subcellular Biochemistry. Ascorbic Acid: Biochemistry and Biomedical Cell Biology. Vol. 25. Of subcellular biochemistry. Springer Science and Business Media, 2013. ISBN: 1461303257, 9781461303251 pp 123130 .

[8] Kays, S. J (1999). Pre-harvest factors affecting appearance post-harvest. Biol tech 15: 233-247.

[9] Omeiza FS, Egu SA and Ologun MC (2017). Determination of $\mathrm{pH}$, sugar and vitamin ' $\mathrm{C}$ ' content of preserved orange juice. Ew J Anal \& Environ Chem 3 (2): 143-145.

[10] UK Essays. (2018). Effect of Temperature on Vitamin C in
Orange Juice. As viewed in https://www.ukessays.com/essays/biology/degradation-ofvitamin-c-in-orange-fruits-biology-essay.php?vref $=1$.

[11] Seung, K. L. and Adel, A. K (2000). Pre-harvest and postharvest factors influencing vitamin $\mathrm{C}$ content of horticultural crops. Postharvest Biology and Technology $20 \mathrm{Pp}$ 207-220.

[12] Ajibola, V. O., Babatunde, O. A. \& Suleiman, S. (2009). The Effect of Storage Method on the Vitamin C Content in Some Tropical Fruit Juices. Trends in Applied Sciences Research, 4: 79-84.

[13] Kuljarachanan T, Devahastin S, and Chiewchan N. (2009). Evolution of antioxidant compounds in lime residues during drying. Food Chemistry, 113 (4) Pp 944-949.

[14] Kurozawa, L. E., Terng, I., Hubinger, M. D., and Park, K. J. (2014). Ascorbic acid degradation of papaya during drying: Effect of process conditions and glass transition phenomenon. Journal of Food Engineering, 123: 157-164.

[15] Abubakar E, and Simon O. (2015). Effect of Temperature and Storage on Vitamin C Content in Fruits Juice. International Journal of Chemical and Biomolecular Science. Vol. 1 (2) pp. 17-21. 